\title{
Induction of extracellular proteinase in Candida albicans
}

\author{
Michio Homma, ${ }^{*} \dagger$ Hiroji Chibana and Kenji Tanaka \\ Laboratory of Medical Mycology, Research Institute for Disease Mechanism and Control, Nagoya University School \\ of Medicine, Showa-ku, Nagoya 466, Japan
}

(Received 25 September 1992; revised 18 January 1993; accepted 29 January 1993)

\begin{abstract}
Pulse-chase experiments indicated that the extracellular proteinase (EPR) of Candida albicans originates as a $45 \mathrm{kDa}$ precursor protein which is processed to a $43 \mathrm{kDa}$ protein prior to secretion. Secretion was routinely stimulated in EPR induction medium which contains bovine serum albumin (BSA) and glucose. Although EPR was not induced without glucose as a carbon source, EPR secretion was induced without the addition of BSA or other nitrogen sources. Furthermore, it was shown that EPR production was not induced at $\mathbf{p H}>6.0$, irrespective of the presence of a nitrogen source. This suggests that medium pH may act directly upon EPR induction, and not as a secondary effect of the nitrogen supply from EPR-mediated protein digestion, which exhibited a pH optimum of around pH 3.5. When germ tube induced cells were transferred to EPR induction medium, EPR was not induced. Thus, EPR production and germ tube formation may not be induced by the same conditions. We speculate that EPR production and germ tube formation do not co-operate in the invasive process but play different and separate roles.
\end{abstract}

\section{Introduction}

The medically important Candida yeasts, $C$. albicans, $C$. tropicalis and $C$. parapsilosis, secrete an extracellular aspartic proteinase (EPR). C. albicans is most frequently isolated as a yeast pathogen in humans (Odds, 1988b). Titres of antibody against EPR occur more often in patients who are $C$. albicans-positive than in negative patients and healthy people (Ishiguro et al., 1992a; Macdonald \& Odds, 1980). However, EPR antibody titres are not useful in the diagnosis of candidiasis (actual infections of $C$. albicans), probably because a fairly high frequency of healthy people also have anti-EPR antibodies and $C$. albicans is commensal in the human mouth, vaginal mucosae and gastrointestinal tract. EPR is thought to be a virulence factor (Odds, $1988 c$; Cutler, 1991). Although its pathological role is not completely clear, it is believed to play an important role during invasive hyphal growth of $C$. albicans. When the fungal cells invade host tissue, they must overcome surface barriers such as skin or mucosa. It has been suggested that EPR secreted by yeast forms of $C$. albicans may degrade surface barrier proteins prior to hyphal form-

*Author for correspondence. Tel. 0527815111 , ext. 6686; fax 0527828575 .

$\dagger$ Present address: Department of Molecular Biology, Faculty of Science, Nagoya University, Chikusa-Ku, Nagoya 464-01, Japan. ation and the deeper invasion into host tissues (Borg \& Ruchel, 1988; Ray \& Payne, 1988; Wingard et al., 1982). EPR may be secreted at hyphal tips and thus assist in tissue invasion, but there is no direct evidence supporting this suggestion.

C. albicans is able to grow in media containing protein as a sole nitogen source because EPR hydrolyses the protein. EPR digests various substrates, such as bovine haemoglobin, BSA, human stratum corneum and others (Negi et al., 1984). It is induced in minimal medium containing protein as a sole nitrogen source (EPR induction medium); however, low molecular mass nitrogen sources, such as amino acids or ammonium sulphate, repress EPR production (Banerjee et al., 1991; Homma et al., 1992; Ross et al., 1990). Glucose also affects the degree of EPR production (Crandall \& Edwards, 1987; Samaranayake et al., 1984).

The $\mathrm{pH}$ optimum for EPR activity is between 3.5 and 4.0 (Germaine \& Tellefson, 1981; Hattori et al., 1984; Remold et al., 1968; Shimizu et al., 1987). Although $C$. albicans can grow at pH 3-7 in Sabouraud broth, it cannot grow at $\mathrm{pH} 6$ or higher in buffered EPR induction medium (Germaine \& Tellefson, 1981; Matsuda, 1986). The lack of EPR production in media at neutral or basic $\mathrm{pH}$ results in a growth defect because nitrogen cannot be supplied by protein degradation. However, it is not clear whether $\mathrm{pH}$ directly affects EPR production. During cell growth, the medium $\mathrm{pH}$ changes from an initial $\mathrm{pH}$ of 
about 3.0 to 7.0 to about $\mathrm{pH} 3.5$ at late exponential phase and then rises to about $\mathrm{pH} \mathrm{7.0} \mathrm{in} \mathrm{the} \mathrm{stationary} \mathrm{phase} \mathrm{in}$ a weakly-buffered medium (Matsuda, 1986).

C. albicans EPR is a $43 \mathrm{kDa}$ protein (Remold et al., 1968; Shimizu et al., 1987). The $43 \mathrm{kDa}$ protein and a $45 \mathrm{kDa}$ form, which cross-reacts with anti-EPR antibody, are detectd in the intracellular space and can be recovered in different membrane fractions (Homma et al., 1992). The $43 \mathrm{kDa}$ protein does not appear to be anchored to the membrane structure and is easily released from such fractions, as would be expected for a secreted enzyme. The intracellular $43 \mathrm{kDa}$ protein was assumed to be the same as the extracellular EPR by the identity of their molecular masses. The $45 \mathrm{kDa}$ protein, called CRM-EPR, is assumed to be a precursor of EPR (Homma et al., 1992). A $54 \mathrm{kDa}$ protein, immunologically detected in translation products of RNA prepared from EPR-induced cells (Banerjee et al., 1991), may also be a precursor protein.

In this study, by using a system developed previously to detect intracellular forms of EPR (Homma et al., 1992), we demonstrate that EPR is produced as a $45 \mathrm{kDa}$ precursor protein, is processed to the $43 \mathrm{kDa}$ form, and excreted into the extracellular space. Furthermore, we examine conditions required for EPR induction by monitoring both extracellular and intracellular EPRs.

\section{Methods}

Strains. The strains of C. albicans used were C9 (Homma et al., 1992; Iwaguchi et al., 1990) and FC18 (Iwaguchi et al., 1990). FC18 strain forms germ tubes efficiently.

Materials. Proteins were radiolabelled using $\operatorname{Tran}^{35} \mathrm{~S}$-label (ICN Biomedicals).

Media. The media used were YPD broth, YNB medium, EPR induction medium, and EPR non-induction medium. EPR induction medium was composed of $2 \%(\mathrm{w} / \mathrm{v})$ glucose and $0.2 \%$ BSA (Sigma) in YNB medium which is a basic medium without carbon and nitrogen sources. The EPR non-induction medium was used as a control medium. It contained $0.1 \mathrm{M}$-ammonium tartrate in the EPR induction medium to suppress EPR production. All the media have been described previously (Homma et al., 1992).

Electrophoresis and immunoblotting. SDS-PAGE and immunoblotting were performed as described by Ishiguro et al. (1992b). Samples for SDS-PAGE were prepared by mixing $50 \mu \mathrm{l}$ protein solution with $10 \mu \mathrm{l} 6 \times \mathrm{TDG}$ buffer $[0.4 \mathrm{M}$-Tris $/ \mathrm{HCl}, \mathrm{pH} 6.8,6 \%(\mathrm{w} / \mathrm{v})$ SDS, $38 \%(\mathrm{w} / \mathrm{v})$ glycerol, $0.006 \%$ bromophenol blue] and $5 \mu \mathrm{l} 2-$ mercaptoethanol. The sample solutions were heated at $100^{\circ} \mathrm{C}$ for $5 \mathrm{~min}$ before being loaded on to the gels.

Anti-EPR serum. Anti-EPR rabbit serum was prepared as described previously (Homma et al., 1992) and was stored at $-80^{\circ} \mathrm{C}$.

Immunoprecipitation of proteins reacting with antibody. Cells were boiled in $1 \%(\mathrm{w} / \mathrm{v})$ SDS and the suspension was diluted 10-fold with TNET buffer ( $50 \mathrm{~mm}$ Tris/HCl, pH 7.8, $0 \cdot 15 \mathrm{M}-\mathrm{NaCl}, 5 \mathrm{~mm}$-EDTA, $1 \%(\mathrm{w} / \mathrm{v})$ Triton $\mathrm{X}-100)$. Immunoprecipitation using protein $\mathrm{A}-$ Sepharose CL-4B was done as described previously (Homma et al., 1985).
Induction of EPR. Induction of EPR was done as described previously (Homma et al., 1992) with the following modifications. Cells were grown to exponential phase $\left(\mathrm{OD}_{660} \simeq 1.0\right)$ in YPD broth containing $1.1 \%(\mathrm{w} / \mathrm{v})$ Casamino acids (Difco) with shaking at $37^{\circ} \mathrm{C}$. They were washed with distilled water, suspended in EPR induction medium (or in control medium) to give an $\mathrm{OD}_{660}$ of 1 or 5 , and incubated with shaking at $37^{\circ} \mathrm{C}$. After further incubation, the cells were sedimented by centrifugation, and both the resulting supernatant and the pellet (suspended in $10 \mathrm{mM}-\mathrm{NaN}_{3}$ to give $\mathrm{OD}_{660}=30$ or 50 ) were analysed by immunoblotting for extracellular and intracellular fractions, respectively.

Induction of germ tube formation. Cells were grown to exponential phase as above for the induction of EPR and were collected by centrifugation. Cells were starved for $2 \mathrm{~h}$ in EPR induction medium without BSA and glucose or in distilled water. This treatment potentiates germ tube formation. The starved cells were collected by centrifugation, and resuspended in distilled water to $\mathrm{OD}_{660}=30$. The cell suspension was diluted 50-fold into EPR non-induction medium containing $10 \%(\mathrm{v} / \mathrm{v})$ bovine calf serum and incubated at $37^{\circ} \mathrm{C}$ for $1 \mathrm{~h}$.

\section{Results}

\section{Pulse-chase experiment}

We detected two intracellular forms of EPR in cells induced to produce it: a $43 \mathrm{kDa}$ protein (EPR) and a $45 \mathrm{kDa}$ protein (cross-reacting material of EPR; CRMEPR) (Homma et al., 1992). To test whether CRM-EPR could be a precursor of EPR, we carried out a pulsechase experiment (Fig. 1). Radiolabelled intracellular CRM-EPR (pre-EPR) was detected first. Intracellular

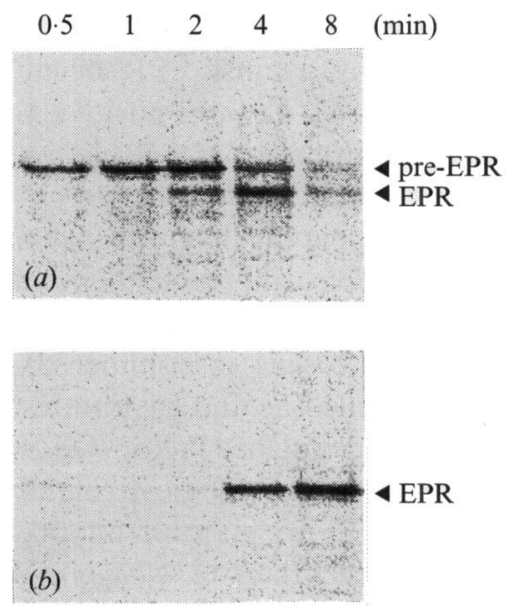

Fig. 1. Pulse-chase experiment. Cells (strain C9) were grown to exponential phase prior to EPR induction and were then suspended in EPR induction medium, incubated at $37^{\circ} \mathrm{C}$ for $1 \mathrm{~h} 45 \mathrm{~min}$ with shaking. A portion $(10 \mu \mathrm{l})$ of ${ }^{35} \mathrm{~S}$ protein labelling mix $(4 \mathrm{MBq})$ was mixed with $500 \mu \mathrm{l}$ cell suspension and incubated for $1 \mathrm{~min}$. Chase solution $(10 \mu \mathrm{l}, 8 \mathrm{~mm}$-methionine, $2 \mathrm{~mm}$-cysteine) was then added. After $0 \cdot 5,1,2,4$ and $8 \mathrm{~min}$, the medium was directly analysed by SDSPAGE $(b)$. Cellular proteins were immunoprecipitated using anti-EPR antiserum, and then analysed by SDS-PAGE (a). Arrowheads show the position of EPR $(43 \mathrm{kDa})$ and of pre-EPR $(45 \mathrm{kDa})$. 


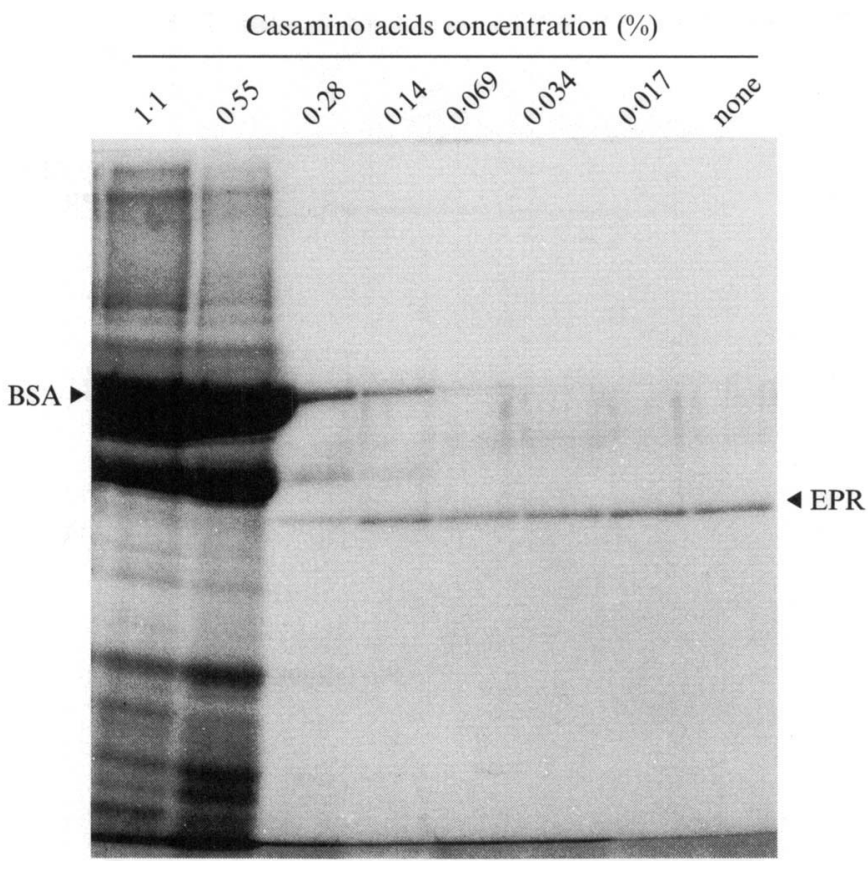

Fig. 2. SDS-PAGE to detect EPR in culture medium with various concentrations of Casamino acids. Stationary cultures $(20 \mu \mathrm{l})$ of strain C9 were inoculated into EPR induction media $(2 \mathrm{ml})$ containing a series of dilutions of $1 \cdot 1 \%$ Casamino acids or no Casamino acids (none). After incubation at $37^{\circ} \mathrm{C}$ for $2 \mathrm{~d}$, cells were removed by centrifugation, the culture media were analysed by SDS-PAGE, and proteins were stained by CBB-R250. Arrowheads on the right and left sides show the positions of EPR and BSA, respectively.

EPR was detected only after 2 min incubation, and by 4 min the radiolabel had shifted to extracellular EPR. Almost all the radiolabel was finally recovered as extracellular EPR after $8 \mathrm{~min}$. This shows that CRMEPR was a precursor form of EPR. CRM-EPR was therefore renamed pre-EPR.

\section{Effect of a low molecular mass nitrogen source upon EPR secretion}

This was determined by varying the concentration of additional Casamino acids in the EPR induction medium. At all concentrations used, the cells achieved stationary phase within $2 \mathrm{~d}$ at $37^{\circ} \mathrm{C}$. Culture medium, analysed by SDS-PAGE (Fig. 2), revealed that EPR was not detected and BSA was not degraded in media containing $1.1 \%(\mathrm{w} / \mathrm{v})$ or $0.55 \%$ Casamino acids. At $0.275 \%$ Casamino acids, EPR secretion was detectable and BSA was degraded, but the amount of the EPR secretion was maximal in media containing $0.138 \%$ Casamino acids or less. If $110 \mathrm{Da}$ is used as the average molecular mass of amino acids, EPR induction is prevented by the addition of greater than $12.5 \mathrm{~mm}$-amino acids (equivalent to $0.138 \%$ ). Other low molecular mass nitrogen compounds, such as glycine, glutamic acid, urea, ammonium tartrate, and ammonium sulphate also gave EPR repression at similar concentrations (data not shown).

\section{Nitrogen and carbon sources required for EPR induction}

To investigate the metabolic requirements of EPR induction, exponential phase cells were transferred into EPR induction medium without BSA, without glucose, or lacking both, and incubated for $2 \mathrm{~h}$. The cells and culture medium were then separated by centrifugation. Samples of the cell suspension and the medium were analysed by electrophoresis and immunoblotting, using an anti-EPR antibody. EPR was detected at reduced levels without BSA (Fig. 3, lane 2), but little was detected when either glucose or both BSA and glucose were omitted (Fig. 3, lanes 1 and 3). This suggests that the presence of glucose in the media is essential for EPR induction, whereas proteins are not required. We did not examine whether other carbon sources act like glucose. The two bands above pre-EPR represent non-specific reaction against anti-EPR antibody (Homma et al., 1992).

The effect of a low molecular mass nitrogen supply was examined further. After cells were incubated in EPR induction medium without BSA for $1 \mathrm{~h}$, various concentrations of Casamino acids were added to the medium. After an additional $1 \mathrm{~h}$ incubation, EPR was detected (Fig. 4). At approximately $3.1 \mathrm{~mm}$-amino acids final concentration, which is equivalent to $0.034 \%$, maximal intracellular EPR and pre-EPR were detected from the band intensities. On the other hand, extracellular EPR levels were elevated at higher concentrations of Casamino acids.

\section{Growth phase and pH effects of EPR induction}

After cells (strain FC18) were transferred to EPR induction medium, EPR was detected within $30 \mathrm{~min}$, and the $\mathrm{pH}$ of the culture medium gradually decreased with the cell growth (Fig. $5 c, d$ ). Intracellular amounts of EPR and pre-EPR reached their maximum per unit cell density after $5-7 \mathrm{~h}$ incubation as extracellular EPR accumulated (Fig. $5 a, b$ ). When maximal levels of EPR were produced, the $\mathrm{pH}$ of the medium was about $3 \cdot 5-4 \cdot 0$, and $\mathrm{OD}_{660}$ of the culture had reached about $6-8$. The immunoreactive bands appearing later are probably degradation products of EPR. Another $C$. albicans strain, $\mathrm{C}$, produced more EPR than FC18 and maximal EPR levels were detected 2-3 h earlier (data not shown).

The effect of the starting $\mathrm{pH}$ of the EPR induction media was determined by adjusting the $\mathrm{pH}$ of the induction medium by addition of $\mathrm{NaOH}$ or $\mathrm{HCl}$ (Fig. $6 a$ ). Incubation was initially at $\mathrm{OD}_{660}=1$ and $\mathrm{pH}$ values 

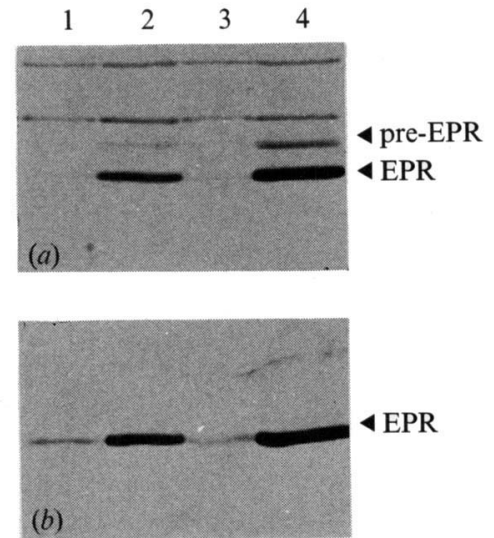

Fig. 3. Immunoblotting to investigate culture nutrient requirements for EPR induction. Cells (strain C9) of an exponential phase culture were suspended in EPR induction medium without both BSA and glucose (lane 1), without BSA (lane 2), without glucose (lane 3) or lacking neither (lane 4). After $2 \mathrm{~h}$ incubation, cellular proteins $(a)$ and culture medium $(b)$ were solubilized by boiling in TDG buffer, analysed by electrophoresis, and immunoblotted using anti-EPR antiserum.
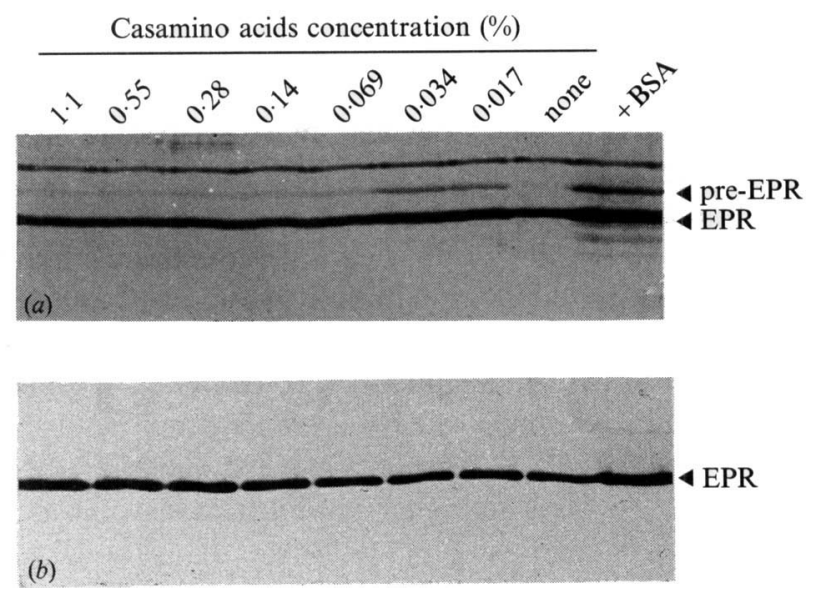

Fig. 4. Effect of Casamino acids concentration on EPR production. Cells (strain C9) of exponential phase culture were suspended in EPR induction medium without BSA. After $1 \mathrm{~h}$ incubation, supplements were added to a series of dilutions of $1.1 \%$ Casamino acids, no Casamino acids (none), and $0.2 \%$ BSA (+BSA). After an additional $1 \mathrm{~h}$, cells and culture medium were analysed by immunoblotting as described in the legend to Fig. 3.

of $2,3,4,5$ and 6 . After $2 \mathrm{~h}$ incubation, $\mathrm{OD}_{660}$ had increased to $2 \cdot 5,2 \cdot 5,3 \cdot 2,3 \cdot 7$ and $3 \cdot 1$, respectively. Maximal EPR levels were seen when the starting $\mathrm{pH}$ was 4.0, whilst little EPR was detected when the starting $\mathrm{pH}$ was 6.0 . This repression may be directly or indirectly due to the $\mathrm{pH}$, as EPR is inactive at $\mathrm{pH} 6$ (Germaine \& Tellefson, 1981; Hattori et al., 1984; Remold et al., 1968; Shimizu et al., 1987), so the available nitrogen source for protein synthesis is not supplied. To resolve this issue, the $\mathrm{pH}$ effect was investigated under EPR induction conditions in the absence of BSA (Fig. $6 b$ ). Although maximal levels of EPR were detected at pH 5.0 or $5 \cdot 5$,

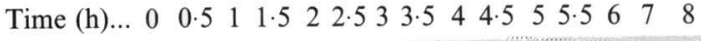
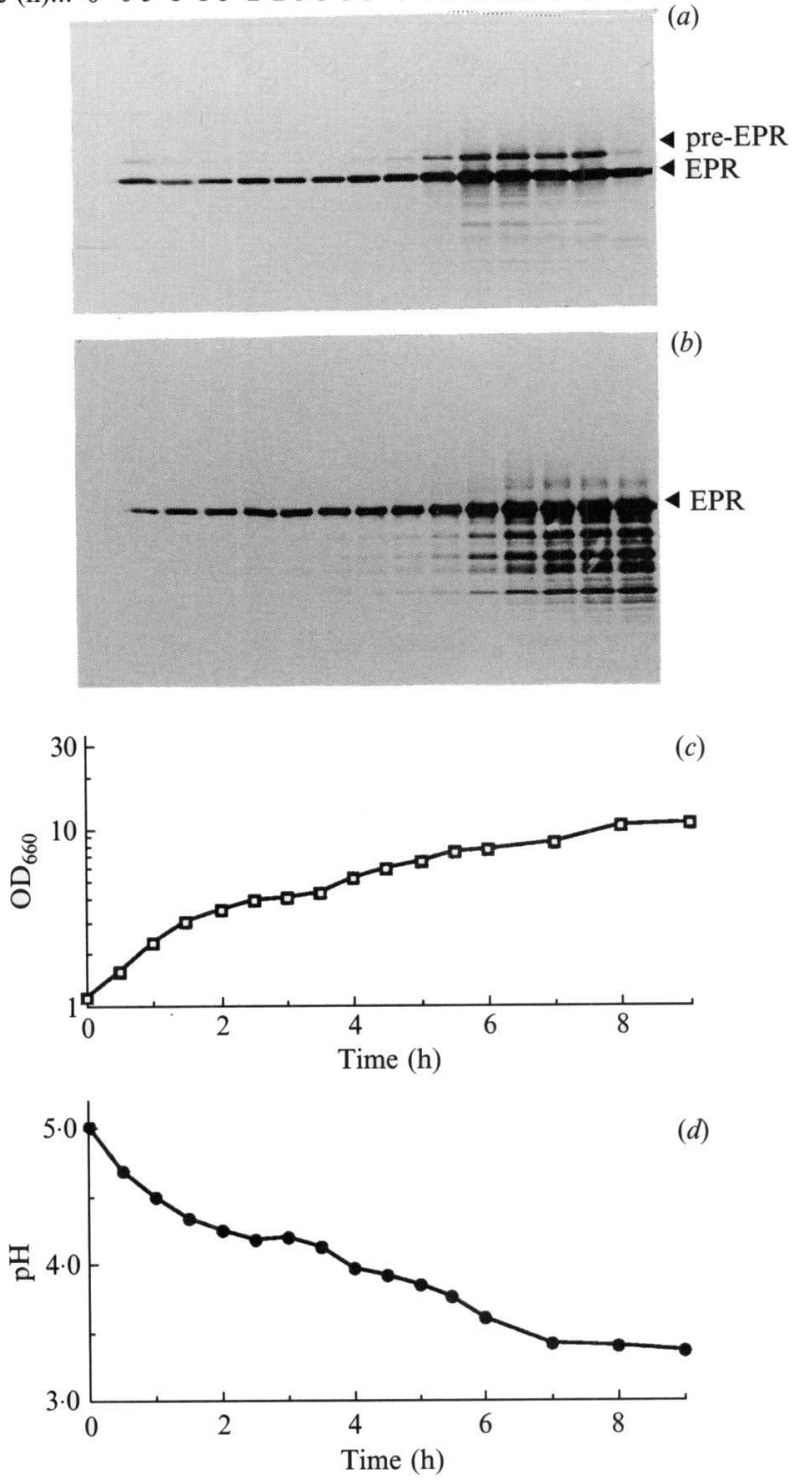

Fig. 5. $\mathrm{pH}$ changes and EPR induction during growth. Cells (strain FC18) of an exponential phase culture were suspended in EPR induction medium. At various times, cells $(a)$ and culture medium $(b)$ were analysed by immunoblotting as described in the legend to Fig. 3 and the $\mathrm{OD}_{660}(c)$ and $\mathrm{pH}$ of the medium $(d)$ were measured.

little EPR was produced above $\mathrm{pH} 6 \cdot 0$. This suggests that high $\mathrm{pH}$ may directly repress EPR induction.

\section{$E P R$ induction during germ tube formation}

It has been suggested that EPR could assist germ tube invasion by digesting the surrounding tissues. Germ tubes form preferentially above neutral $\mathrm{pH}$ (around pH 6.0) (Odds, 1985, 1988a); however, we have shown that EPR induction requires low $\mathrm{pH}$. We therefore wanted to determine whether EPR is actually produced by germ tube cells. Starved cells (strain FC18) were 


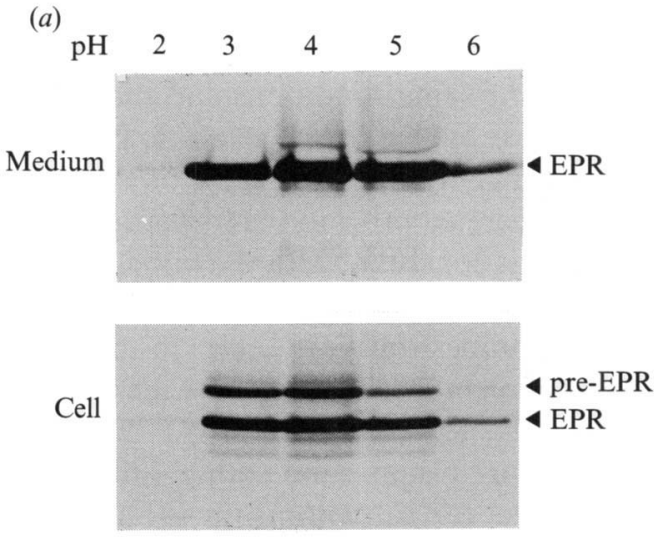

(b)

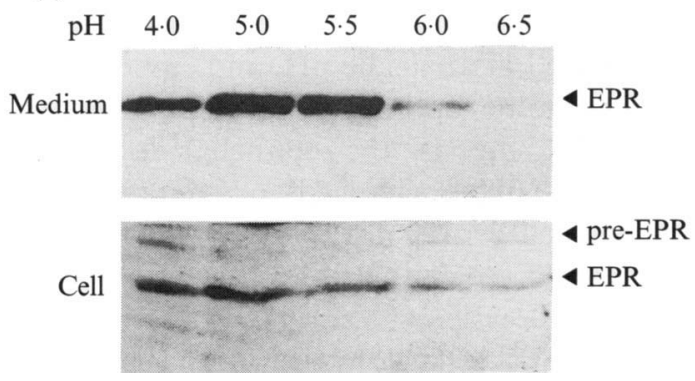

Fig. 6. Effects of medium pH on EPR induction. Cells (strain C9) of an exponential phase culture were suspended in EPR induction medium (a) and EPR induction medium without BSA (b), whose $\mathrm{pH}$ was adjusted by $\mathrm{HCl}$ or $\mathrm{NaOH}$ to the indicated value, at a cell density of $\mathrm{OD}_{660}=1 \cdot 0$. The medium used in $(b)$ was buffered with $25 \mathrm{~mm}$-sodium citrate. After $2 \mathrm{~h}$ incubation at $37^{\circ} \mathrm{C}$, cells and culture medium were analysed by immunoblotting as described in the legend to Fig. 3.

incubated in EPR non-induction medium containing $10 \%$ bovine calf serum at $37^{\circ} \mathrm{C}$. After $1 \mathrm{~h}$ incubation, at least $80 \%$ of cells formed germ tubes and were transferred to EPR induction medium. When comparable amounts of germ tube and yeast cells were analysed by immunoblotting, EPR was not detected in germ tubes until yeast cells started to propagate (data not shown).

\section{Discussion}

The detection of intracellular EPR as well as extracellular EPR is essential to clarify the mechanisms underlying EPR induction. Without this information, it is impossible to distinguish between defects in transport and synthesis when EPR is not detected in the culture medium. By immunological detection we found two intracellular forms of EPR; a $43 \mathrm{kDa}$ and a $45 \mathrm{kDa}$ protein (Homma et al., 1992). These were previously assumed to represent the mature extracellular EPR and a precursor form, respectively. In the studies reported here, we used a pulse-chase experiment to confirm this prediction. In this experiment, radiolabel of the intracellular $45 \mathrm{kDa}$ protein clearly shifted to the intracellular $43 \mathrm{kDa}$ protein, and then to the extracellular $43 \mathrm{kDa}$ protein. In addition to the $45 \mathrm{kDa}$ precursor form, $54 \mathrm{kDa}$ and $47 \mathrm{kDa}$ immunologically related proteins have been reported. The $54 \mathrm{kDa}$ protein, which was not detected in our previous study (Homma et al., 1992) or the present report, was detected as a translation product from C. albicans $\mathrm{mRNA}$ in vitro (Banerjee et al., 1991). The $47 \mathrm{kDa}$ protein was copurified with $45 \mathrm{kDa}$ pre-EPR in our previous study (Homma et al., 1992). As secretory proteins are usually processed to a mature form by way of several intermediate precursor forms (Reid, 1991), the $54 \mathrm{kDa}$ or the $47 \mathrm{kDa}$ protein might be precursors for the $45 \mathrm{kDa}$ pre-EPR. From the amino acid sequence deduced from the DNA sequence data (Hube et al., 1991), the molecular masses of the unprocessed and mature proteins are estimated to be 41.7 and $36.1 \mathrm{kDa}$, respectively, provided that the proteins are not modified post-translationally by additions such as sugar residue addition. The difference between protein sizes estimated by SDS-PAGE and from DNA sequence data have not been clarified.

EPR production was repressed when the cells were grown in a medium containing more than about $12.5 \mathrm{~mm}-$ amino acids (Fig. 2). The actual concentration required for repression is probably lower than $12.5 \mathrm{mM}$, because they are catabolized and their concentrations thus decrease during cell growth. Other low molecular mass nitrogen sources also repress EPR production. This may show that its production is controlled by certain key compounds of nitrogen metabolism.

It has been supposed to date that proteins in the EPR induction medium are essential for EPR production. However, we found that EPR was produced and secreted into a medium that lacks protein and that EPR was not induced in a medium lacking glucose even in the presence of a protein source (Fig. 3). On the other hand, Crandall \& Edwards (1987) reported that nitrogen starvation did not induce $C$. albicans EPR, leading them to suggest that proteins acted as both a substrate and an inducer of EPR. Our results do not support this possibility. Their conclusion was derived from evidence that EPR was not detected in a medium with glucose and without a nitrogen source after $4 \mathrm{~d}$ incubation. In that experiment, cells could not grow because of a lack of alternative nitrogen source; thus all protein synthesis decreased or stopped, and EPR production was inhibited. This interpretation is supported by the following arguments. When EPR-induced cells which had been incubated in a medium without nitrogen source or protein were transferred into a medium containing varying concentrations of Casamino acids, intracellular EPR and pre-EPR levels were maximal with $3.1 \mathrm{~mm}$-amino acids, but extracellular levels were maximal at higher concentrations which repressed EPR production (Fig. 4). These results suggest that a high concentration of a low molecular mass 
nitrogen source may activate protein synthesis but that excess nitrogen source may repress EPR induction. On the other hand, at lower concentrations of the nitrogen source (around $3.1 \mathrm{~mm}$ ), protein synthesis was activated to some extent without the repression of EPR induction. EPR induction and repression seem to be regulated by a very delicate balance of nitrogen supply.

Nitrogen and carbon metabolism are interrelated and regulated in a complex manner (Marzluf, 1981; Wiame et al., 1985). Glutamate and glutamine are amino donors in the flow of nitrogen into organic compounds, and glutamate dehydrogenase (GDH), which functions in the biosynthesis of glutamate from ammonia, is thought to play a pivotal role in nitrogen metabolism. Increasing amounts of inorganic nitrogen compounds repress yeast NADP-GDH activity (Bogonez et al., 1985; Holmes et al., 1989; Uno et al., 1984) and there is a loss of this activity in medium lacking glucose (Mazon, 1978; Mazon \& Hemmings, 1979). It will be interesting to determine whether the nitrogen-sensing system for GDH regulation is similar to that underlying EPR regulation.

During C. albicans culture, the $\mathrm{pH}$ of the medium falls in late exponential or early stationary phase, before returning to neutral values in late stationary phase (Mazon, 1978). Similar pH changes were observed in our EPR induction system with extracellular EPR accumulating during the cultivation. The highest intracellular EPR levels were detected at late exponential phase when the $\mathrm{pH}$ of the medium was around 3.5 (Fig. 5). The increase in intracellular EPR levels, normalized with respect to cell density, can be explained by either increased synthesis or decreased EPR secretion.

We examined the effect of medium $\mathrm{pH}$ on EPR synthesis. No induction was found in medium of neutral $\mathrm{pH}$ either with or without BSA, suggesting that EPR induction is directly affected by the $\mathrm{pH}$ of the medium (Fig. 6). The optimal initial $\mathrm{pH}$ was 4.0 for EPR induction medium with BSA, but 5.0 or 5.5 for EPR induction medium without BSA. This difference in $\mathrm{pH}$ optima between medium with and without BSA may be explained as follows. The optimal $\mathrm{pH}$ for EPR induction is probably around 5.0 or 5.5 ; however, cells grow more actively at around $\mathrm{pH} 4.0$ in the presence of BSA because a nitrogen source is being supplied by the degradation of BSA by EPR, whose optimal pH is 3.5-4.0 (Germaine \& Tellefson, 1981; Hattori et al., 1984; Remold et al., 1968; Shimizu et al., 1987).

Transformation conditions of yeast and hyphal forms have been examined extensively (for review see Odds, $1985,1988 a$ ). Medium $\mathrm{pH}$ is one of the most important factors in the dimorphic switch. Neutral $\mathrm{pH}$ is usually necessary for hyphal formation, but inhibits EPR induction. We therefore examined EPR production in germ-tube induced cells transferred to EPR induction medium. No EPR was detected. This may show that EPR production and germ tube formation are not induced under the same conditions and that EPR is not always secreted at hyphal tips. Therefore, EPR secretion by hyphal cells may not be necessary for tissue invasion if EPR can be secreted prior to the formation of hyphae. This suggestion is consistent with the evidence that EPRdeficient strains cannot usually invade chick chorioallantoic membranes but are able to do so if the chorioallantoic membrane is treated with purified EPR (Kobayashi et al., 1989; Shimizu et al., 1987).

Based on our results and other information, a speculative model for $C$. albicans invasion is presented, although the real in vivo process is probably more complicated. First, a cell attaches to a epithelial layer. EPR is induced at an acidic $\mathrm{pH}$, and environmental $\mathrm{pH}$ is changed to the optimal $\mathrm{pH}$ for EPR. Second, the secreted EPR digests the epithelial layer, and the environmental $\mathrm{pH}$ is changed to a more neutral $\mathrm{pH}$. Finally, the cell germinates to give hyphal growth and invades beyond the epithelial layer.

We thank J. E. Cutler (Montana State Univ.) for critically reading the manuscript.

This work was supported by grants-in-aid for scientific research from the Ministry of Education, Science, and Culture in Japan.

\section{References}

BanerJeE, A., Ganesan, K. \& Datta, A. (1991). Induction of secretory acid proteinase in Candida albicans. Journal of General Microbiology 137, 2455-2461.

Bogonez, E., Satrustegui, J. \& Machado, A. (1985). Regulation by ammonium of glutamate dehydrogenase $\left(\mathrm{NADP}^{+}\right)$from Saccharomyces cerevisiae. Journal of General Microbiology 131, 1425-1432.

BORG, M. \& RUCHEL, R. (1988). Expression of extracellular acid proteinase by proteolytic Candida spp. during experimental infection of oral mucosa. Infection and Immunity 56, 626-631.

Crandall, M. \& Edwards, J. E. (1987). Segregation of proteinasenegative mutants from heterozygous Candida albicans. Journal of General Microbiology 133, 2817-2824.

Cutler, J. E. (1991). Putative virulence factors of Candida albicans. Annual Review of Microbiology 45, 187-218.

Germaine, G. R. \& Tellefson, L. M. (1981). Effect of pH and human saliva on protease production by Candida albicans. Infection and Immunity 31, 323-326.

Hattori, M., Yoshiura, K., Negi, M. \& Ogawa, H. (1984). Keratinolytic proteinase produced by Candida albicans. Journal of Medical and Veterinary Mycology 22, 175-183.

Holmes, A. R., Collings, A., Farnden, K. J. F. \& Shepherd, M. G. (1989). Ammonium assimilation by Candida albicans and other yeasts: evidence for activity of glutamate synthase. Journal of General Microbiology 135, 1423-1430.

Homma, M., Kutsukake, K. \& Iino, T. (1985). Structural genes for flagellar hook-associated proteins in Salmonella typhimurium. Journal of Bacteriology 163, 464-471.

Homma, M., Kanbe, T., Chibana, H. \& Tanaka, K. (1992). Detection of intracellular forms of secreted aspartic proteinase in Candida albicans. Journal of General Microbiology 138, 627-633.

Hube, B., TuRver, C. J., OdDs, F. C., EIfFert, H., Boulnois, G. J., KoCHel, H. \& RUCHEL, R. (1991). Sequence of the Candida albicans gene encoding the secretory aspartate proteinase. Journal of Medical and Veterinary Mycology 29, 129-132. 
Ishiguro, A., Homma, M., Sukai, T., Higashide, K., Tori, S. \& TANAKA, K. (1992a). Detection of antigen components of Candida albicans by reaction with antibody from candidial vaginitis patients and healthy females. Journal of Medical and Veterinary Mycology $\mathbf{3 0}$, 281-292.

Ishiguro, A., Homma, M., ToriI, S. \& TanaKA, K. (1992b). Identification of Candida albicans antigens reacted with IgE antibody of human sera. Infection and Immunity 60, 1550-1557.

Iwaguchi, S.-I., Homma, M. \& TanaKa, K. (1990). Variation in the electrophoretic karyotype analysed by the assignment of DNA probes in Candida albicans. Journal of General Microbiology 136, 2433-2442.

Kobayashi, I., Kondoh, Y., Shimizu, K. \& TanaKa, K. (1989). A role of secreted proteinase of Candida albicans for the invasion of chick chorio-allantoic membrane. Microbiology and Immunology 33, 709-719.

MaCDONald, F. \& OdDs, F. C. (1980). Purified Candida albicans proteinase in the serological diagnosis of systemic candidosis. Journal of the American Medical Association 243, 2409-2411.

MARZLUF, G. A. (1981). Regulation of nitrogen metabolism and gene expression in fungi. Microbiological Reviews 45, 437-461.

MATSUDA, K. (1986). Influence of nitrogen source, $\mathrm{pH}$ of media and Candida albicans-producing proteinase (CAPP) (=keratinolytic proteinase; KPase) on the growth of $C$. albicans. Japanese Journal of Medical Mycology 27, 100-106.

Mazon, M. J. (1978). Effect of glucose starvation on the nicotinamide adenine dinucleotide phosphate-dependent glutamate dehydrogenase of yeast. Journal of Bacteriology 133, 780-785.

Mazon, M. J. \& Hemmings, B. A. (1979). Regulation of Saccharomyces cerevisiae nicotinamide adenine dinucleotide phosphate-dependent glutamate dehydrogenase by proteolysis during carbon starvation. Journal of Bacteriology 139, 686-689.

Negi, M., TsuboI, R., Matsui, T. \& OgaWA, H. (1984). Isolation and characterization of proteinase from Candida albicans: substrate specificity. Journal of Investigative Dermatology 83, 32-36.

ODDs, F. C. (1985). Morphogenesis in Candida albicans. CRC Critical Reviews in Microbiology 12, 45-93.
OdDs, F. C. (1988a). Morphogenesis in Candida, with special reference to C. albicans. In Candida and Candidosis, pp. 42-59. London: Bailliere Tindall.

ODDs, F. C. $(1988 b)$. Ecology of Candida and epidemiology of candidosis. In Candida and Candidosis, pp. 68-92. London: Bailliere Tindall.

OdDs, F. C. (1988c). Pathogenesis of Candidosis. In Candida and Candidosis, pp. 252-278. London: Bailliere Tindall.

RAY, T. L. \& PAYNe, C. D. (1988). Scanning electron microscopy of epidermal adherence and cavitation in murine candidiasis: a role for Candida acid proteinase. Infection and Immunity 56, 1942-1949.

REID, G. A. (1991). Protein targeting in yeast. Journal of General Microbiology 137, 1765-1773.

Remold, H., Fasolk, H. \& Staib, F. (1968). Purification and characterization of a proteolytic enzyme from Candida albicans. Biochimica et Biophysica Acta 167, 399-406.

Ross, I. K., De Bernardis, F., Emerson, G. W., Cannone, A. \& Sullivan, P. A. (1990). The secreted aspartate proteinase of Candida albicans: physiology of secretion and virulence of a proteinasedeficient mutant. Journal of General Microbiology 136, 687-694.

Samaranayake, L. P., Hughes, A. \& Macfarlane, T. W. (1984). The proteolytic potential of Candida albicans in human saliva supplemented with glucose. Journal of Medical Microbiology 17, 13-22.

ShimiZu, K., KondoH, Y. \& TANAKA, K. (1987). Proteinase production and pathogenicity of Candida albicans. Microbiology and Immunology 31, 1045-1060.

Uno, I., Matsumoto, K., Adachi, K. \& Ishikawa, T. (1984) Regulation of NAD-dependent glutamate dehydrogenase by protein kinases in Saccharomyces cerevisiae. Journal of Biological Chemistry 259, 1288-1293.

WiAME, J. M., Grenson, M. \& ARST, H. N. (1985). Nitrogen catabolite repression in yeasts and filamentous fungi. Advances in Microbial Physiology 26, 1-88.

Wingard, J., Dick, J., Merz, W., SANdford, G., Saral, R. \& Burns, W. (1982). Differences in virulence of clinical isolates of Candida tropicalis and Candida albicans in mice. Infection and Immunity 37, 833-836 